\title{
The production performance of lactating Jersey cows receiving varying levels of lucerne hay and oat silage as roughage sources
}

\author{
N.M. Bangani ${ }^{1}$, J.A. Botha ${ }^{1}$, C.J.C. Muller ${ }^{1}$ and C.W. Cruywagen ${ }^{2}$ \\ ${ }^{1}$ Chief Directorate: Agriculture: Private Bag X1, Elsenburg 7607, South Africa; ${ }^{2}$ Department of Animal Sciences, University \\ of Stellenbosch, South Africa \\ Email: noluvuyob@wcape.agric.za
}

\section{Introduction}

Nutrition is one of many factors that affects milk yield in dairy cows. Increasing the protein concentration in the supplement increases milk yield of cows receiving grass silage based diets (Huhtanen et al., 1995). Gross margins for purchased feed per litre milk produced can be reduced by decreased feeding of purchased concentrates and replacement with cheaper home-produced roughages (Browne et al., 1995). In the Western Cape, oat silage is often used in combination with lucerne hay or wheat straw in the feeding of dairy cows (Muller \& Botha, 1998). No information is available concerning the ideal combination of oat silage and lucerne hay for dairy cows. The objectives of this study were to determine the production performance of lactating dairy cows receiving varying levels of oat silage and lucerne hay and to determine the maximum level of oat silage that can be included in the diet without impairing the performance of cows.

\section{Materials and Methods}

The investigation was conducted at the Elsenburg Research Station situated in the winter rainfall region of South Africa. Oats was ensiled at the soft dough stage. After preservation, it was fed to 10 multiparous Jersey cows from 8 weeks post-calving onwards. Cows were randomly allocated to five treatments according to a 5 x 5 latin square experimental design. Treatments were: ad libitum oat silage together with lucerne hay fed at $0,2,4,6$ or $8 \mathrm{~kg}$ dry matter $(\mathrm{DM})$ per day and concentrates containing various crude protein $(\mathrm{CP})$ levels i.e. 26, 23, 20, 17 and $14 \% \mathrm{CP}$. Concentrate mixtures were formulated in such a way that the total diets of the cows were isonutritious. The $26 \% \mathrm{CP}$ concentrate was fed with a $100 \%$ oat silage diet while the $14 \% \mathrm{CP}$ concentrate was fed with a $100 \%$ lucerne hay diet. Each feeding period consisted of a 2-week adaptation period and a 3-week experimental period. Cows were kept in individual stalls to determine roughage intakes. Fresh roughage (lucerne hay and oat silage fed separately) was provided to the cows every afternoon. Fresh drinking water was available $a d$ libitum inside each stall. The dry matter intake of cows was monitored twice a week. Refusals from the previous feeding were collected and weighed before providing fresh feed. Feed samples were collected once a week during the experiment and analysed for chemical composition. Dried material was subjected to laboratory analysis for $\mathrm{CP}$ and crude fibre contents according to the methods of the AOAC (1990). The TDN content was determined according to the method of Engels \& Van der Merwe (1967). Oat silage was evaluated weekly for pH and dry matter content. Cows were machine-milked twice a day at 05:00 and 15:30 and the milk yield of each cow recorded. Combined milk samples of the afternoon and morning milking were collected twice a week, mixed and analysed for fat, protein and lactose content using a Milko-Scan Infrared Analyser. Production and feed intake data were analysed by multi-factor analysis of variance.

\section{Results and Discussion}

With the exception of protein production, there were no significant $(\mathrm{P}>0.05)$ differences in production parameters for cows receiving different levels of lucerne hay and ad libitum oat silage (Table 1). Cows receiving oat silage as the sole source of roughage had lower DM-intakes than cows receiving varying amounts of lucerne hay plus oat silage or lucerne hay alone. These results accord with those of Browne et al. (1995), who found higher mean DM-intakes by replacing one third, or more, of a grass silage with an alternative forage. According to these authors, increased feed intakes from such forage mixtures usually results in higher milk yields and gross income. In our study, however, no differences in milk production occurred between treatments. Although the MUN values were fairly high, values below $25 \mathrm{mg} / \mathrm{dl}$ are still within the acceptable range for individual cows and for the type of forage used. 
Short paper and poster abstracts: $38^{\text {th }}$ Congress of the South African Society of Animal Science

Table 1 Production performance of multiparous Jersey cows receiving different amounts of lucerne hay and ad libitum oat silage together with a concentrate mixture

\begin{tabular}{|c|c|c|c|c|c|c|c|}
\hline \multirow{2}{*}{ Parameters } & \multicolumn{5}{|c|}{ Lucerne provided (kg DM/day) } & \multirow{2}{*}{ SEM } & \multirow{2}{*}{$\mathrm{P}$} \\
\hline & 0 & 2 & 4 & 6 & 8 & & \\
\hline \multicolumn{8}{|l|}{ Production (kg/day): } \\
\hline Milk & 16.3 & 17.0 & 16.9 & 17.2 & 17.2 & 0.271 & 0.18 \\
\hline Fat $(\%)$ & 4.72 & 4.53 & 4.63 & 4.69 & 4.63 & 0.077 & 0.48 \\
\hline Fat & 0.76 & 0.76 & 0.77 & 0.79 & 0.78 & 0.017 & 0.52 \\
\hline FCM & 17.88 & 18.17 & 18.25 & 18.74 & 18.60 & 0.323 & 0.36 \\
\hline Protein (\%) & 3.46 & 3.50 & 3.46 & 3.54 & 3.53 & 0.432 & 0.55 \\
\hline Protein & $0.55^{\mathrm{abc}}$ & 0.57 & $0.59^{\mathrm{a}}$ & $0.59^{\mathrm{b}}$ & $0.60^{\mathrm{c}}$ & 0.106 & 0.04 \\
\hline Lactose $(\%)$ & 4.76 & 4.74 & 4.74 & 4.79 & 4.80 & 0.028 & 0.44 \\
\hline \multicolumn{8}{|l|}{ Feed intake (kg/day): } \\
\hline Lucerne & 0.00 & 1.54 & 2.71 & 4.24 & 7.75 & 0.38 & 0.001 \\
\hline Silage & 6.87 & 6.13 & 5.19 & 4.33 & 0.00 & 0.183 & 0.001 \\
\hline Concentrates & 6.24 & 6.25 & 6.29 & 6.28 & 6.29 & 0.017 & 0.21 \\
\hline Total DMI & $13.12^{\mathrm{ab}}$ & 13.92 & $14.15^{\mathrm{a}}$ & $14.85^{\mathrm{b}}$ & 14.05 & 0.349 & 0.03 \\
\hline EFC (milk/kg feed) & 1.24 & 1.22 & 1.19 & 1.16 & 1.27 & 0.633 & 0.85 \\
\hline MUN (mg/dl) & 20.93 & 21.24 & 20.59 & 20.53 & 23.05 & 0.017 & 0.17 \\
\hline
\end{tabular}

a,b,c Means within rows with the same superscripts, differ significantly $(\mathrm{P}<0.05)$; SEM: Standard error of means; DMI: dry matter intake; FCM: 4\% fat corrected milk; EFC: efficiency of feed conversion; MUN: milk urea nitrogen

\section{Conclusion}

Oat silage can be used successfully as the major forage source for dairy cows in the Western Cape, but inclusion in the diet of at least $2 \mathrm{~kg}$ lucerne hay/cow/day is recommended to ensure sufficient DM-intake and milk protein production.

\section{References}

AOAC, 1990. Association of analytical chemists. Official Methods of Analysis. 15 ${ }^{\text {th }}$ ed., Washington, D.C

Browne, I., Allen, D., Phipps, R. \& Sutton, J., 1995. Mixed Forage Diets for Dairy Cows. Summary of a MMB Sponsored Research Project, Cedar, U.K.

Engels, E. A. N. \& Van Der Merwe, F. J., 1967. Application of an in vitro technique to South African forages with special reference to the effect of certain factors on the results. S. Afr. J. Agric. Sci. 10, 983-995.

Huhtanen, P., Jaakkola, S. \& Saarisalo, E., 1995. The effects of concentrate energy source on the milk production of dairy cows given a grass silage-based diet. Anim. Sci. 60, 31-40.

Muller, C. J. C. \& Botha, J. A., 1998. Soetlupienkuilvoer of hawerhooi as ruvoer vir lakterende Jerseykoei. Elsenburg Journal 2, 38-41.

Thomas, P. C., \& Rae, R. C., 1988. Concentrate supplementation of silage for dairy cows. Nutrition and lactation in the dairy cow: $327-354$. 